\title{
BELT \& ROAD INITIATIVE AND RUSSIA: FROM MISTRUST TOWARDS COOPERATION
}

\author{
LADISLAV ZEMÁNEK
}

\begin{abstract}
The aim of this article is to analyse relations between China and Russia over the Belt and Road Initiative (BRI) in the context of deepening Sino-Russian relations and the general rise of Eurasia. China and Russia are pivotal non-Western Eurasian powers in political, economic and military terms and the key motors of Eurasian multi-faceted integration. Both countries pursue their own interests and present their own projects and initiatives. Nevertheless, over the last few years, Sino-Russian cooperation has become strategic and is starting to pursue a new model of globalisation and international order. In the article, I refer to this approach as the "New Eurasian Paradigm" (NEP). I follow Axel Honneth's Hegelian-based theory of threefold-level recognition Hrubec (2011, p. 267). which I extend and employ at the interstate level to interpret the behaviour of China and Russia and their integration projects in terms of a struggle for political recognition as full, equal members of the global community determining global processes. Both countries thus aim to reform the global order and boost the integration of Eurasia in order to achieve successful development. These common interests are the main reasons behind their mutual strategic collaboration.
\end{abstract}

Keywords: China; Russia; Eurasia; Belt and Road Initiative; New Eurasian Paradigm

\section{Introduction}

Given that cooperation between Beijing and Moscow has been taking place in different formats and contexts, I will proceed as follows: First, I will examine the BRI in the broader context of Eurasian integration processes with regard to the Eurasian Economic Union (EAEU) and Shanghai Cooperation Organisation (SCO), in which both great powers play a leading role. These projects are integral to Chinese and Russian politics and interests as formulated in the last few years. The normative principles common to the BRI, EAEU and SCO (NEP) are analysed along with the negotiations and prospects of convergence between the integrations, taking Sino-Russian relations into account. I then go on to examine the China-Mongolia-Russia Economic Corridor and the New Eurasian Land Bridge, analysing the means of cooperation, specific projects and the potential risks. This method should shed light on the current and prospective role played by the BRI in Sino-Russian relations, which are crucial to Eurasian integration. 


\section{BRI and the New Eurasian Paradigm}

The Belt and Road Initiative was unveiled by President Xi Jinping in Astana. This was no coincidence as the former Kazakh leader Nursultan Nazarbayev is a key proponent of Eurasian integration and connectivity and actively pursued it from the very beginning of his presidency in 1991. The aim of the BRI is to integrate Eurasia, making it the heart of a new international order and thereby establishing a new form of globalisation (Lukyanov, 2014, p. 18) and global civilisation (Wang, 2016, p. 13). ${ }^{1}$ In this sense, the Chinese initiative coincides with other Eurasian integration projects, the most important of which are the Shanghai Cooperation Organisation, Eurasian Economic Union and the Greater Eurasian Partnership. All of them are part of the pursuit for a more equal, democratic, inclusive, diverse and fairer international order based on the peaceful principles of coexistence. ${ }^{2}$ As such, these projects directly contradict the unilateralism, hegemonism and neoliberalism, represented by the Washington Consensus, that their participants are so critical of (Lukin, 2015, p. 3). ${ }^{3}$

Non-Western Eurasian states that support these projects strongly emphasise the principles of sovereignty, non-interference, territorial integrity, sustainable development, security, stability and a plurality of political systems conceiving their own participation in integration as a pathway to incorporation in the global economy. Unlike Western political standards, direct and full participation in the BRI, EAEU or SCO is not conditional on political, institutional or legal reforms. ${ }^{4}$ Both China and Russia prefer to maintain the stability of the existing regimes while making gradual changes (Bordachev, 2016, pp. 6-7). The absence of political and ideological dictates, which is related by some scholars to Western politics accusing the West of imperialism (Kirkham, 2016, p. 121), can be explained as the result of negative experience with Western "universalism" and of recognition of the right to selfdevelopment. Thus, the new global paradigm can be conceptualised as the view of the emancipating and ascendant non-Western world. Given that Eurasian states are the main initiators and movers of this shift in the global arena and that the integration of Eurasia is crucial to redefining the international order, I will call this new approach to the global order the "New Eurasian Paradigm".

\footnotetext{
${ }^{1}$ I follow Hann's concept of Eurasia connecting the ancient concepts of Asia and Europe in an indeterministic, constructivist way, taking account of deep historical interactions and affinities among Eurasian peoples and cultures. These are characterised by "inclusive embeddedness" or the embeddedness of the economic sphere in a broader social framework and the subordination of the economy to social needs and moral norms and imperatives. Hann's concept of Eurasia is based on ethnographic research and aims to situate Eurasia at the centre of historical development (Hann, 2016, pp. 1-27).

${ }_{2}$ See Vision and Actions (2015), Charter (2001), Dogovor (2014) and Plenarnoe zasedanie (2016).

3 From one point of view, this vision of democratisation of the international order and norms envisaged by states with authoritative characteristics may seem paradoxical. Nevertheless, the democratisation at the international level is intended to generate more inclusivity and participation, giving voice to countries and cultures which have been overlooked and marginalised within the present order that is dominated by Western actors and their norms.

4 Political disputes and controversies relating to the BRI and SCO are to be solved solely through political means (especially bilateral and multilateral negotiations), while legal disputes will be solved in accordance with the national legislation stipulated in the agreement or treaty. As the EAEU is more institutionalised, legal cases are arbitrated by the Court of the Eurasian Economic Union.
} 
It follows that the BRI is not just an economic initiative motivated by strictly economic stimuli but a complex, multi-layered project that can be interpreted in terms of emancipation, recognition and reformism. ${ }^{5}$ Taking into consideration the fact that China and Russia represent the leading actors in non-Western Eurasia, their cooperation and relations are pivotal to the successful integration of Eurasia and implementation of the values of the New Eurasian Paradigm, embodied in the BRI, the EAEU and the SCO (Diesen, 2017, p. 8; Vinokurov, 2017, p. 66).

\section{The BRI and the EAEU}

Russia's original position towards the BRI was predominantly sceptical. The Kremlin was afraid that Beijing was endeavouring to undermine Russian-led integration efforts in Eurasia and create a competing infrastructure which would harm the Trans-Siberian Railway. Russia's attitude changed once China accepted the Russian requirement that the EAEU should become a full and equal partner to Beijing in the region (Timofeev, Lissovolik, \& Filippova, 2017, p. 64). As Russia attaches great significance to the EAEU, in this section I will cover the negotiations on it and the BRI and the relationship between the two projects.

In May 2015 the initial phase of negotiations ended successfully with the signing of a joint declaration on linking the two integration projects and creating a free-trade area (FTA). The two sides also set out the priorities of cooperation: expanding trade, maintaining stability, the sustainable development and economic integration of the region, establishing joint industrial parks and trans-border economic zones, improving connectivity and infrastructure, supporting small and medium-sized enterprises and conducting mutual financial transactions in national currencies (Sovmestnoe zayavlenie, 2015).

The second phase of the negotiations between Chinese and Russian representatives on convergence between the BRI and EAEU involved drawing up a list of joint infrastructure and transport projects, talks on harmonising legal, technical and tariff regulations between the two economic areas and an agreement on trade and economic cooperation that would create the legal framework for mutual economic relations. By 2017 the Eurasian Economic Commission had prepared priority projects relating to the construction and modernisation of infrastructure, logistics centres and key transport hubs, such as a motorway corridor connecting Western Europe with Western China, the high-speed Moscow-Kazan railway, a railway linking China, Kyrgyzstan and Uzbekistan and another one between the Russian cities of Arkhangelsk, Komi and Perm, establishing a new way for Chinese goods to be transported to Europe via the planned port at Arkhangelsk. The latter coincided with the Belkomur project already under construction. All in all, between 2015 and 2017 the EAEU proposed 38 joint projects to their Chinese counterparts (Sopryazhenie, 2017; Transport i logistika, 2017).

\footnotetext{
5 China and Russia are reformist states pursuing changes to selected aspects of the international order without rejecting it en bloc. This runs counter to (neo)realist power transition theory; its proponents tend to consider China, Russia and other allegedly revisionist states a source of tension and conflict in international relations. See Sergunin (2016, pp. 25, 27-29).
} 
The second phase of collaboration culminated in the signing of the agreement on trade and economic cooperation between China and the EAEU in May 2018. The agreement regulates 13 areas including customs and trade procedures, intellectual property protection, the reduction of non-tariff barriers and support for e-commerce, transparency and information exchange (Podpisano Soglashenie, 2018). Interestingly, the importance of regional integration through the convergence of the BRI and the EAEU is mentioned in the preamble (Agreement, 2018). Yet, the path towards the FTA remains long. Some optimistic Chinese academics think the common Eurasian economic area can be established by 2030 (Zhang, 2016, p. 3).

Another Sino-Russian deal, reached in 2015, is designed to effectively coordinate cooperation and convergence between the BRI and the EAEU. The leaders of China and Russia decided that the SCO would be a suitable platform (Kaczmarski, 2017, p. 1036). China considers this multilateral organisation to be a suitable vehicle for pursuing the BRI as it brings together such important partners as India, Kazakhstan and Pakistan, and Iran as observer state. ${ }^{6}$ Moreover, some Chinese politicians, businessmen and scholars would like to see the European Union join the organisation (Wang, 2016, p. 68). Incidentally, in 2016 the SCO member states generated more than 20 per cent of global GDP and accounted for virtually 42 per cent of the world's population. Taking into consideration development tendencies, we can expect the SCO to become further established as an important regional actor with a reformist agenda and global impact. It therefore seems mutually advantageous for it to work more closely with the BRI. While the SCO serves as a political platform, projects arising from agreements made at the political level can be undertaken and implemented within the BRI framework. In addition, the SCO may contribute considerably to improving relations in Eurasia, both among the EAEU states and between the EAEU/ Russia and China.

It is important to stress that there are considerable structural differences between the EAEU and the BRI, and these could lead to tensions. Whilst the EAEU is designed as an EU-like integration project, China's BRI is not an attempt to create an institutionalised structure with legal subjectivity. On the contrary, it represents a new model of cooperation and international relations based primarily on the political will and commitment of participating state actors (Kaczmarski, 2017, p. 1029). Nevertheless, both projects share the same normative principles as pertain to the New Eurasian Paradigm. In addition, convergence between the BRI and the EAEU could offset the shortcomings in the latter. These stem from the obvious power asymmetry between the majority of the member states on one hand and Russia on the other, the substantial correlation between EAEU development and the Russian economy and politics, the limited labour force, capital and high-tech, different attitudes towards currency and fiscal policy, structural homogeneity between member states, and isolation or instability in border regions (Kirkham, 2016, p. 118; Sergi, 2018, pp. 53-54).

The EAEU now accounts for 3.2 per cent of global GDP and no-one seriously thinks it will become a self-sufficient market. It follows that the BRI can provide it with what it lacks,

\footnotetext{
6 The other SCO members are Kyrgyzstan, Tajikistan and Uzbekistan. It also develops strategic cooperation with observer states such as Afghanistan, Belarus, and Iran and Mongolia.
} 
primarily the capital for building modern and competitive infrastructure. It would facilitate and accelerate integration, strengthening the EAEU's position as a bridge between Europe and East Asia (Timofeev, Lissovolik, \& Filippova, 2017, p. 66).

\section{The BRI in the context of Sino-Russian relations}

The Chinese initiative came at the right time. After the 2008 global economic crisis, both Eurasian great powers started looking for new ways to stimulate their own development and growth (Kaczmarski, 2017, p. 1031). Beijing followed its go global strategy, whereas Moscow endeavoured to reintegrate the post-Soviet area, which led it to the EAEU, finally established in January 2015. Insofar as the timing is concerned, the BRI coincided with Russia's deep disillusionment with the West, triggered by EU and NATO expansion eastwards, military interventions in Yugoslavia, Iraq and Libya, the proposed US anti-missile systems in Europe and the wave of "colour revolutions" in the Arab world and post-Soviet states, especially Georgia, Kyrgyzstan and Ukraine (Bratersky, 2014). These events led the Russian leadership to redefine external ties and reinforced the older tendency to pursue a balanced multi-vector policy (Karaganov et al., 2017, p. 8). The sharp deterioration in European-Russian relations was accompanied by anti-Russian sanctions and a fall in oil and gas prices that led to the Russian economic recession of 2015 and 2016 (Li, 2016, p. 5). All these factors forced the Kremlin to change its course. Putin's third term is thus characterised by a pivot to the East, both in external and internal politics. However, this did not mean renouncing possible cooperation and partnership with Europe as can be seen in Russia's Foreign Policy Concept, which considered the common economic space between the EU and EAEU a strategic task (Koncepciya vneshnej politiki, 2016). It also contained a new conception of the Greater Eurasian Partnership which envisioned an integrated Eurasia encompassing the EAEU, BRI, SCO, but also APEC and the EU (Mezhdunarodny'j forum, 2017).

There is therefore greater opportunity than ever before to deepen ties between Russia and China and develop the BRI. Over the last 30 years, Sino-Russian relations gradually improved before reaching a peak under the Xi Jinping leadership. Closest cooperation takes place in energy and security, reinforcing mutual interdependence. China is also Russia's main trade partner (Gvosdev \& Marsh, 2014, pp. 133-134). Meetings and talks are held frequently and regularly on different levels and in different configurations, from the SCO, BRICS and the RIC (Russia-India-China forum) to exclusive presidential visits. Their similar attitudes and co-ordinated steps can even be seen in the international arena. The apparent increase in harmony has led some to talk of a strategic partnership, despite such a positive image being rejected by a majority of Western scholars (Sangar, 2017, pp. 3-4).

Mutual relations undoubtedly face several serious risks. Apart from historical animosities and Russian concerns about the growing power of the Chinese (Kashin, 2014, p. 100; Kirkham, 2016, p. 122), the two countries' interests could collide in Central Asia. Moreover, this conflict potential has been intensified by the BRI consolidating Chinese economic dominance in the region. Nevertheless, Beijing still respects Russian political and security interests in Central Asia, thereby maintaining the balance and preventing the Kremlin from being exposed to serious threat (Kaczmarski, 2017, p. 1043). The positive development of 
Sino-Russian relations and the integration of Eurasia through the convergence of the BRI, EAEU, SCO and other projects relies on each taking the other's interests into account and giving up on any hegemonic pretences. The opposite policy would be in total contradiction to the principles of the New Eurasian Paradigm and would do irreversible harm to the new vision of an integrated Eurasia.

\section{The BRI corridors and Russia}

Turning now from wider Sino-Russian relations to the BRI, we need to identify the various corridors. Here though we are referring to a much more complex phenomenon than just the infrastructure, since the Chinese leadership has designed the BRI as the means and basis for achieving multi-layered cooperation and joint projects in a wide array of fields (Bond, 2017, p. 6). The corridors therefore divide up the geographical area in which collaboration is to be commenced. Two out of the six continental corridors include Russia: the China-MongoliaRussia Economic Corridor (CMREC) and the New Eurasian Land Bridge (NELB), immediately adjacent to the China-Central Asia-West Asia Economic Corridor (CCWAEC).

\section{China-Mongolia-Russia Economic Corridor}

The CMREC project was unveiled by Xi Jinping on the margins of the $14^{\text {th }} \mathrm{SCO}$ summit in Dushanbe in September 2014. Since then, two constitutive documents have been elaborated by the three sides - the Roadmap (2015) and Programme (2016) — setting out the main priorities and contours of the projects. Corridor policy is set at trilateral presidential summits and has so far been focused predominantly on transport and energy infrastructure, trade and tourism. Leaders from all participating countries have supported the idea of linking the BRI with other strategies and development plans, especially the EAEU, Mongolian Steppe Road ${ }^{7}$ and the Russian programme set out in the Socioeconomic Development of the Russian Far East and the Baikal Region (2014), which envisages the building of gas and oil pipelines, new industrial centres and the development of high-tech in non-European Russia (Zhang \& Zhang, 2017, pp. 162-163; Buyankhishig, 2016).

When presenting the CMREC in Dushanbe, President Xi underlined improvements to transport connectivity, the construction of an international energy network, support for tourism and cooperation in media and civil society and environmental protections. The Russian president stressed energy, transport infrastructure and mining. The leaders agreed that cooperation should be deepened through the SCO (Xinhua, 2014; Xi Jinping Attends Meeting, 2014). The next meeting was held during the $15^{\text {th }}$ SCO summit in Ufa in July 2015 and gave rise to the Roadmap, two framework agreements on trilateral trade and entry terminals (Xinhua, 2015). The third meeting was held on the occasion of the SCO summit in Tashkent in June 2016. The economic corridor programme was signed, as laid out in the Roadmap. It focused on expanding trade exchange, improving infrastructure and competitive

\footnotetext{
7 The Steppe Road is a state project launched in 2012 with the aim of connecting China with Russia by means of a complex infrastructure network and transforming Mongolia into a transport and logistic hub in Eurasia.
} 
products and simplifying trans-border transport (Xi Jinping, 2016). Given the emphasis on the importance and potential of the SCO platform, both the Chinese and Russian presidents agreed Mongolia should be fully involved in the SCO, as confirmed at the trilateral summit in Qingdao in June 2018 (Xinhua, 2018). Regular contact at the ministerial and expert level is another important mechanism for cooperation.

The CMREC Roadmap sets out six areas of possible collaboration, namely trilateral politics, security, economy and trade, trans-border and regional cooperation, people-to-people exchange and international politics (Dorozhnaya karta, 2015). The CMREC Programme fleshes out the general direction outlined in the Roadmap. The first point concerns improvements to transport infrastructure, including the smooth circulation of people, goods and vehicles, boosting transit potential, the development of joint navigation systems, the operation of regular international container transports and the construction of logistic centres. The second point focuses on the reconstruction of border crossings and harmonising customs and control procedures. The third point relates to deepening cooperation in energy, mining, high-tech development, agriculture, forestry and investment. The next point deals with trade and economic cooperation and the related construction of trans-border economic zones, improvements to the mutual trade structure and services development. The fifth point relates to collaboration in education, science, technology, culture, tourism, people-to-people exchanges, health and intellectual property protection. Environmental protection and ecology come fourth, and regional cooperation is last (Programma, 2016).

The CMREC Programme also lists priority projects, including the following of special importance to Sino-Russian relations: (1) modernisation of the central railway corridor connecting Ulan-Ude and Naushki in Russia with Sükhbaatar, Ulaanbaatar and ZamynÜüd in Mongolia and Erenhot, Zhangjiakou, Beijing and Tianjin in China; (2) preparations for construction of the Western railway corridor linking the Russian city of Kuragino with Ürümqi, the capital of Xinjiang Uigur Autonomous Region, via Mongolian territory; (3) preparations for the construction of the Eastern railway corridor between Borzya in Russia, Choibalsan in Mongolia and Chifeng and Jinzhou in China; (4) preparations for the modernisation of the Zarubino-Choibalsan-Ulanhot motorway corridor; and (5) preparations for establishing an economic zone in the Chinese province of Heilongjiang and the adjacent Russian regions. All the projects will be financed by the state, private companies or through public-private partnerships (PPP) with assistance from the AIIB, New Development Bank (BRICS), SCO Interbank Consortium, Silk Road Fund and other national and multilateral financial institutions (Programma, 2016). If constructed, this infrastructure network and the expanding gas and oil pipelines to China would contribute to the development of Siberia and the Russian Far East which are both in need of North-South connectivity. Nevertheless, the outcome of these plans remains to be seen. So far, two significant transport infrastructure projects are under construction: a railway bridge over the Amur (Heilong) river connecting Tongjiang and Nizhneleninskoye, and the first motorway bridge between the two countries crossing the same river and linking Heihe with Blagoveshchensk (Goncharoff, 2018; China Daily, 2016). Negotiations are also ongoing on visa-free movement between the two cities (Xinhua, 2017).

Among other things, the aim of the BRI is to develop China's border provinces and autonomous regions, connecting them with neighbouring states including the Russian Far 
East (Timofeev, Lissovolik, \& Filippova, 2017, p. 66). Given its character, the Chinese Initiative is highly compatible with Russia's official development strategy for Siberia and the Russian Far East, considered a national $21^{\text {st }}$ century priority by President Putin (Poslanie Prezidenta, 2013). ${ }^{8}$ Although the strategy coincides with Russia's recent pivot to Asia, and reflects the transfer of the centre of global economic dynamic and growth from West to East Asia (Bordachev, 2017), it still has untapped potential as the BRI is predominantly EastWest orientated, whereas Siberia and especially the Russian Far East require North-South connectivity (Timofeev, Lissovolik, \& Filippova, 2017, p. 66). From this point of view, the current China-Mongolia-Russia Economic Corridor seems insufficient.

\section{New Eurasian Land Bridge}

There is no formalised or institutionalised platform for interstate cooperation relating to the New Eurasian Land Bridge (NELB). Individual projects are therefore usually based on bilateral agreements. Multilateral negotiations are held on broader platforms such as the SCO, Conference on Interaction and Confidence-Building Measures in Asia (CICA), $16+1$ and China-Europe. It follows that NELB can be described as the most extensive yet amorphous of the corridors, since it is discussed via other formats and platforms, for instance, $16+1$ or China-Europe summits.

NELB can be seen as an infrastructure project to supplement existing connections from China to Europe, or as an improvement to the current corridors. So far, the two remote corners of the vast Eurasian continent have been linked with three spinal corridors: (1) a northern one that corresponds to the Trans-Siberian Railway (TSR); (2) a central one running via Kazakhstan to Russia where it joins the TSR; and (3) a southern one from the Kazakh city of Aktau over the Caspian Sea to Azerbaijan, Georgia and Turkey, or bypassing the Caspian Sea to Iran. The first two corridors are the most fully utilised, partly because of the single customs area guaranteed by the EAEU (Shepard, 2017). Technically speaking, NELB coincides with the central corridor and the ambition is to connect the Pacific, or more precisely the Yellow Sea, with the Baltic Sea and Atlantic Ocean, while boosting the development of Xinjiang and Central Asia and contributing to the establishment of a Eurasian FTA (Li, 2014).

Construction on the corridor did not start as a result of the BRI, but the fresh Chinese Initiative has given strong impetus to its development and expansion. Prior to 2011, there were no regular cargo trains between China and Europe. By 2017 there were regular connections between 48 Chinese and more than 40 European cities. In 2015 a total of 815 trains ran, but by 2017 that had increased more than fourfold to 3,600 trains. In addition, the journey lasted no fewer than 36 days prior to 2011, compared to 16 days in 2017 (Xinhua, 2016; China Daily, 2018). Apart from developing railway infrastructure, conditions for road transport have been developed, as can be seen in the almost 8,500 km long Western EuropeWestern China motorway corridor opened by president Nazarbayev in 2012. Drivers can reach Europe in a mere 10 days (Shepard, 2016).

\footnotetext{
8 The declared purpose of this strategy is to turn the thus far overlooked region into a modern, proexport industrial base, and that is inconceivable without linking it to the ascendant Asia-Pacific.
} 
As there is no formalised NELB platform or any official documents, it is hard to identify the projects making up the corridor. Should we include projects like the construction of the high-speed railway between Moscow and Kazan as part of a much more ambitious vision of a Eurasian railway corridor from Beijing to the Russian capital and beyond in the NELB portfolio? The same question applies to the construction of the Power of Siberia and Altai/Power of Siberia-2 pipelines being constructed by PetroChina in collaboration with Gazprom with the aim of transporting Russian gas to China. These projects were mentioned by presidents $\mathrm{Xi}$ and Putin at the 2015 summit marking the signing of the agreement on the convergence of the BRI and EAEU (Zayavleniya, 2015). However, NELB was not mentioned.

\section{Conclusion}

The BRI, EAEU, SCO and Greater Eurasian Partnership are all part of the New Eurasian Paradigm (NEP) as a specific approach to and concept of international relations and a global order that corresponds to the new conditions of a multipolar world characterised by the concurrent processes of globalisation and regionalisation (Söderbaum, 2003, p. 5). The NEP is based on the principles of equality, inclusivity, openness, sovereignty, independence, territorial integrity, non-aggression, non-interference, sustainable development and the market economy. The principles of human rights and democracy are also included, but it is a specific, illiberal interpretation reflecting the Chinese and Russian political models in practice, which are characterised by their emphasis on the community and its interests as well as common, shared values. ${ }^{9}$ These imperatives stem predominantly from the interests of the political elites of the key actors in non-Western Eurasia.

Sino-Russian relations have been undergoing a period of unprecedented improvement. The degree of mutual trust and agreement in national interests makes the convergence of the BRI with the Russian-promoted EAEU feasible. Nevertheless, the two powers are striving for much broader integration of the Eurasian macro-region, rather than limiting themselves to a prospective China-EAEU free trade area. This creates the conditions for developing the BRI with the involvement of other actors, be they states or regional organisations. Achieving the existing visions will require the elimination of risks and weaknesses in Sino-Russian relations and the strengthening of a shared identity and Eurasia-oriented thinking.

Since its inception, the BRI, or more specifically the CMREC agenda, has remained stable, which is indicative of the mutual understanding between the two countries. There are no points of contention over the construction of the BRI between China and Russia. Insofar as the CMREC is concerned, plans and projects already exist, some of which are already being realised. Besides the two corridors, a wide range of joint projects are ongoing, but none of those involved have explicitly indicated that these are part of the BRI. Nevertheless, such projects could well be subsumed under the BRI agenda, as they follow its intrinsic "logic".

In conclusion, it would not be out of place to note here that there has been frequent disorganisation in the interaction and cooperation mechanisms between the actors involved

9 This statement reflects Hann's description of the nature of Eurasian societies. See Hann (2016, p. 4). 
in the BRI. The initiatives are not always synchronised and sometimes compete with one another. I think the participating actors could strive for greater transparency, more rules and a degree of institutionalisation to facilitate cooperation, deepen trust and, last but not least, improve efficiency.

\section{References}

Agreement on Economic and Trade Cooperation between the Eurasian Economic Union and Its Member States, of the One Part, and The People's Republic of China, of The Other Part (2018). Retrieved January 04, 2019, from http://greater-europe.org/wp-content/uploads/2018/06/ зсткитайанглкоп.pdf.

Bond, I. (2017). The EU, the Eurasian Economic Union and One Belt, One Road. Can they work together?. Retrieved November 03, 2018, from https://cer.eu/sites/default/files/pb_eurasian_ IB_16.3.17_0.pdf.

Bordachev, T. (2016). Russia and China in Central Asia: The Great Win-win Game. Retrieved January 03, 2019, from http://valdaiclub.com/files/11127/

Bordachev, T. (2017, December 28). Main Results of 2017: Energetic Russia and the Greater Eurasia Community. Retrieved January 01, 2019, from http://valdaiclub.com/a/highlights/main-results-of2017-energetic-russia/

Bratersky, M. (2014, June 07). Transformation of Russia's foreign policy. Retrieved November 15, 2018, from https://eng.globalaffairs.ru/number/Transformation-of-Russias-Foreign-Policy--16706

Buyankhishig, O. (2016, November 18). Mongolia-China-Russia Economic Corridor. Retrieved November 17, 2018, from http://nigscass.cssn.cn/xshy/201701/W020170303349361882465.pdf

Charter of the Shanghai Cooperation Organization (2001). Retrieved December 30, 2018, from eng. sectsco.org/load/203013/

China Daily (2016, December 24), Highway bridge to link China, Russia. Retrieved October 29, 2018, from http://www.china.org.cn/business/2016-12/24/content_39978318.htm

China Daily (2018, August 27), Freight train fetes 10,000th Europe trip. Retrieved December 29, 2018, from http://www.ecns.cn/business/2018-08-27/detail-ifyxikfc9642958.shtml

Diesen, G. (2017). Russia, China and 'Balance of Dependence' in Greater Eurasia. Retrieved December 10, 2018, from http://valdaiclub.com/files/13795/

Dogovor o Evrazijskom e'konomicheskom soyuze [Treaty on the Eurasian Economic Union] (2014). Retrieved January 01, 2019, from https://docs.eaeunion.org/docs/ru-ru/0003610/itia_05062014

Dorozhnaya karta razvitiya sotrudnichestva mezhdu Rossijskoj Federaciej, Kitajskoj Narodnoj Respublikoj i Mongoliej na srednesrochnuyu perspektivu [Mid-term Roadmap for the Development of Trilateral Co-operation between China, Russia and Mongolia] (2015). Retrieved November 19, 2018, from http://static.kremlin.ru/media/events/files/ru/jF9vhkLz06L18dUCuntCCJ7n099fAfxk.pdf

Goncharoff, P. (2018, August 03). Russia and China build bridges together, successfully fulfill MAJOR infrastructure projects. Retrieved November 27, 2018, from https://theduran.com/together-chinaand-russia-have-bridged-the-black-dragon/

Gvosdev, N. K., \& Marsh, C. (2014). Russian foreign policy: Interests, vectors, and sectors. Thousand Oaks: CQ Press; London: SAGE Publications.

Hann, C. (2016). A concept of Eurasia. Current Anthropology, 57(1), 27.

Hrubec, M. (2011). Od zneuznání ke spravedlnosti. Kritická teorie globální společnosti a politiky [From misrecognition to justice: Critical theory of the global society and politics]. Praha: Filosofia.

Kaczmarski, M. (2017). Two ways of influence-building: The Eurasian Economic Union and the One Belt, One Road Initiative. Europe-Asia Studies, 69(7), 1027-1046. 
Karaganov, S. A. et al. (2017). K velikomu okeanu 5: ot povorota na Vostok k Bol'shoj Evrazii [Toward the Great Ocean 5: From the turn to the east to Greater Eurasia]. Retrieved January 06, 2019, from http://ru.valdaiclub.com/files/17048/

Kashin, V. (2014). Russia turns to Asia. In K. Liik (Ed.), Russia's "Pivot" to Eurasia (pp. 95-101). London: European Council on Foreign Relations.

Kirkham, K. (2016). The formation of the Eurasian Economic Union: How successful is the Russian regional hegemony? Journal of Eurasian Studies, 7(2), 111-128.

Koncepciya vneshnej politiki Rossijskoj Federacii [Concept of the Foreign Policy of the Russian Federation] (2016, December 01). Retrieved November 27, 2018, from http://www.mid.ru/foreign_ policy/news/-/asset_publisher/cKNonkJE02Bw/content/id/2542248

Li, X. (2014, May 04). The new Asian fusion. Retrieved January 01, 2019, from http://www.china.org. cn/opinion/2014-05/04/content_32278791.htm

$\mathrm{Li}, \mathrm{X}$. (2016). Chinese perspective on the creation of a Eurasian Economic Space. Retrieved January 04, 2019, from http://valdaiclub.com/files/12585/

Lukin, A. (2015). Shanghai Cooperation Organization: Looking for a new role. Retrieved January 02, 2019, from http://valdaiclub.com/files/11400/

Lukyanov, F. (2014). Building Eurasia and defining Russia. In K. Liik (Ed.), Russia's "Pivot" to Eurasia (pp. 18-24). London: European Council on Foreign Relations. Retrieved August 12, 2018, from https://www.ecfr.eu/page/-/ECFR103_RUSSIA_COLLECTION_290514_AW.pd.

Mezhdunarodny 'j forum «Odin poyas, odin put"» [Belt and Road International Forum] (2017, May 14). Retrieved November 30, 2018, from http://kremlin.ru/events/president/news/54491

Plenarnoe zasedanie Peterburgskogo mezhdunarodnogo e'konomicheskogo foruma [Plenary Session of the Saint Petersburg International Economic Forum] (2016, June 17). Retrieved December 30, 2018, from http://kremlin.ru/events/president/news/52178

Podpisano Soglashenie o torgovo-e 'konomicheskom sotrudnichestve mezhdu EAE'S i KNR [EAEUPRC Trade and Economic Cooperation Agreement signed] (2018, May 17). Retrieved January 02, 2019, from http://www.eurasiancommission.org/ru/nae/news/Pages/17-05-2018-5.aspx

Poslanie Prezidenta Federal'nomu Sobraniyu [Presidential Address to the Federal Assembly] (2013, December 12). Retrieved November 25, 2018, from http://kremlin.ru/events/president/news/19825

Programma sozdaniya e konomicheskogo koridora Kitaj-Mongoliya-Rossiya [Programme for the creation of the China-Mongolia-Russia economic corridor] (2016). Retrieved November 20, 2018, from http://minpromtorg.govrb.ru/rus-ch-mn.pdf

Sangar, K. (2017). Russia and China in the age of grand Eurasian projects: Prospects for integration between the Silk Road Economic Belt and the Eurasian Economic Union. Cambridge Journal of Eurasian Studies, 1, 1-15.

Sergi, B. S. (2018). Putin's and Russian-led Eurasian Economic Union: A hybrid half-economics and half-political "Janus Bifrons". Journal of Eurasian Studies, 9(1), 52-60.

Sergunin, A. (2016). Explaining Russian Foreign Policy Behavior. Theory and Practice. Stuttgart: Ibidem Press.

Shepard, W. (2017, April 17). Multiple Routes Between China And Europe Is Why The New Silk Road Is A Real Game Changer. Retrieved November 22, 2018, from https://www.forbes.com/sites/ wadeshepard/2017/04/17/multiple-routes-between-china-and-europe-is-why-the-new-silk-road-is-areal-game-changer/\#39569bc1feba

Shepard, W. (2016, July 10). The Western Europe-Western China Expressway To Connect The Yellow Sea With The Baltic. Retrieved November 22, 2018, from https://www.forbes.com/sites/ wadeshepard/2016/07/10/the-western-europe-western-china-expressway-to-connect-the-yellow-seawith-the-baltic/\#6cce26d66c95

Söderbaum, F. (2003). Introduction: Theories of New Regionalism. In F. Söderbaum \& T. M. Shaw (Eds.), Theories of New Regionalism (pp. 1-21). Houndmills: Palgrave Macmillan. 
Sopryazhenie EAE'S i E'PShP priobretaet real'ny'e ochertaniya: soglasovan spisok infrastrukturny'x proektov [Pairing of the EAEU and SREB acquires real outlines: the list of infrastructure projects has been agreed] (2017, March 01). Retrieved January 02, 2019, from http://www. eurasiancommission.org/ru/nae/news/Pages/2-03-2017-1.aspx

Sovmestnoe zayavlenie Rossijskoj Federacii i Kitajskoj Narodnoj Respubliki o sotrudnichestve po sopryazheniyu stroitel'stva Evrazijskogo e'konomicheskogo soyuza i E'konomicheskogo poyasa Shelkovogo puti [Joint Statement on Cooperation on the Construction of Joint Eurasian Economic Union and the Silk Road Projects] (2015, May 08). Retrieved December 29, 2018, from http:// kremlin.ru/supplement/4971

Timofeev, I., Lissovolik, Y., \& Filippova, L. (2017). Russia's vision of the Belt and Road Initiative: From the Rivalry of the Great Powers to Forging a New Cooperation Model in Eurasia. China \& World Economy, 25(5), 62-77.

Transport i logistika mogut stat' drajverami e 'konomicheskogo rosta $v$ EAE'S [Transport and logistics can become the drivers of economic growth in the EAEU] (2017, December 08). Retrieved January 02, 2019, from http://www.eurasiancommission.org/ru/nae/news/Pages/8-12-2017-2.aspx

Vinokurov, E. (2017). Eurasian Economic Union: Current state and preliminary results. Russian Journal of Economics, 3(1), 54-70.

Vision and Actions on Jointly Building Silk Road Economic Belt and 21st-Century Maritime Silk Road (2015, March 28). Retrieved December 29, 2018, from http://en.ndrc.gov.cn/newsrelease/201503/ t20150330_669367.html

Wang, Y. (2016). The Belt and Road Initiative. What will China offer the world in its rise. Beijing: New World Press.

Xi Jinping Attends Meeting (2014, September 09). Retrieved November 29, 2018, from https://www. fmprc.gov.cn/mfa_eng/topics_665678/zjpcxshzzcygyslshdsschybdtjkstmedfsllkydjxgsfw/t1191093. shtml

Xi Jinping Chairs the Third Meeting of Heads of State of China, Russia and Mongolia (2016, June 23). Retrieved November 30, 2018, from https://www.fmprc.gov.cn/mfa_eng/zxxx_662805/t1375409. shtml.

Xinhua (2014, September 12), Xi calls for China-Mongolia-Russia economic corridor. Retrieved November 29, 2018, from http://www.china.org.cn/wap/2014-09/12/content_33494551.htm

Xinhua (2015, July 10), Xi urges quickened construction of China-Russia-Mongolia economic corridor. Retrieved November 29, 2018, from http://www.china.org.cn/world/Off_the_Wire/2015-07/10/ content_36024865.htm

Xinhua (2016, July 23), Feature: China-Europe freight trains bring vitality to ancient Silk Road. Retrieved November 29, 2018, from http://www.china.org.cn/world/Off_the_Wire/2016-07/23/ content_38940787.htm

Xinhua (2017, November 17), Chinese, Russian cities in talks to open visa-free road travel. Retrieved December 29, 2018, from http://www.china.org.cn/china/Off_the_Wire/2017-11/13/ content_41884626.htm

Xinhua (2018, June 10), China, Russia, Mongolia vow to strengthen cooperation. Retrieved November 29, 2018, from http://www.china.org.cn/world/2018-06/10/content_51920327.htm

Zayavleniya dlya pressy " po itogam rossijsko-kitajskix peregovorov [Press statements following Russian-Chinese talks] (2015, May 08). Retrieved December 28, 2018, from http://www.kremlin.ru/ events/president/transcripts/49433

Zayavleniya dlya pressy " po itogam rossijsko-kitajskix peregovorov [Press statements following Russian-Chinese talks] (2017, July 04). Retrieved December 29, 2018, from http://www.kremlin.ru/ events/president/news/54979

Zhang, X. (2016). Has “Coordination” Started? Russian Analytical Digest, 183, 2-5. 
Zhang, X., \& Zhang, S. (2017). China-Mongolia-Russia Economic Corridor and Environmental Protection Cooperation. R-Economy, 33, 161-166. Retrieved November 20, 2018, from http://reconomy.ru/wp-content/uploads/2017/10/r-economy_2017_v3_3_04.pdf

Institute of Global History

Faculty of Arts

Charles University

Nám. Jana Palacha 2

11638 Prague 1

Czech Republic

Email: zemanek.ml@gmail.com 